\title{
Groundcovers, Organic and Inorganic Mulches, and Masonry Surfaces Differentially Affect Establishment and Root Zone Characteristics of Urban Trees
}

\author{
Michael A. Arnold and Garry V. McDonald
}

\begin{abstract}
Three experiments investigated the effects of various groundcovers on establishment of redbuds [Cercis canadensis $\mathrm{L}$. var. texensis (S. Watson) M. Hopkins 'Alba'] and baldcypress [Taxodium distichum (L.) Rich.]. The first experiment involved eight surface treatments. Controls were bare soil. Remaining treatments were pine bark mulch; Asian jasmine [Trachelospermum asiaticum (Siebold \& Zucc.) Nakai]; St. Augustinegrass [Stenotaphrum secundatum (Walt.) Kuntze]; decorative gravel; recycled paper mulch; decorative brick pavers; or seasonal rotations of herbaceous annuals. Other experiments compared brick-on-sand treatments ranging in color from light blonde to dark charcoal with bare soil on establishment of redbuds or baldcypress. Most organic and living soil surface covers were preferable to bare soils, however, some inorganic surface covers were detrimental to tree growth. Paving surfaces adversely affected survival, shoot or root growth, but differences were species dependent. Soil moisture, $\mathrm{pH}$, and bulk density did not appear to be limiting under pavers, but substantial seasonal fluctuations in soil temperatures were observed. Light and medium bricks reflected more photosynthetically active radiation than dark bricks or bare soil. Atmospheric temperatures were greatest above dark and medium bricks. Root growth decreased as darkness of brick color increased. Redbud survival and growth were more adversely affected than with baldcypress.

Key Words. Baldcypress; Brick-on-Sand Paving; Cercis canadensis var. texensis; Groundcovers; Herbaceous Annuals; Inorganic Mulch; Organic Mulch; Plant Competition; Redbud; Taxodium distichum; Transplant Establishment; Tree Establishment.
\end{abstract}

In situations that permit the space, many arboriculture practitioners recommend mulching trees to the extent of the drip line or beyond (Carlson 2002). However, tree establishment in urban environments often occurs in limited rooting volumes, such as planting pits in sidewalks or in parking lot islands. Soil surface covers can be highly variable, depending on the pedestrian traffic and intended use in the area, in addition to the level of maintenance desired. Inorganic groundcovers, such as decorative gravel or brick-on-sand pavers may be used where heavy pedestrian traffic is anticipated while areas with lighter foot traffic may involve the use of organic mulches or living groundcovers such as turfgrass or vines. Areas with high visibility may be covered with decorative organic groundcovers, including pine bark; or rotations of seasonal herbaceous annuals (seasonal color changes) may be planted cyclically throughout the year in beds beneath the trees. In other cases, environmentally friendly soil surface covers, such as recycled paper products, may be used.

While studies have addressed various characteristics of mulches relative to their durability (Litzow and Pellett 1983; Skroch et al. 1992; Duryea et al. 1999), attractiveness (Ashworth and Harrison 1983; Skroch et al. 1992; Duryea et al. 1999), effects on soil physical or chemical characteristics (Stephenson and Schuster 1945; Fraedrich and Ham 1982; Watson 1988; Hartz and Giannini 1998; Duryea et al. 1999), and to a limited extent their absorption or reflectance of sunlight or heat (Kjelgren and Montague 1998), information is limited about their relative effects on tree establishment. In most cases, information on tree establishment is limited to studies investigating nonliving organic groundcovers, such as composted or chipped mulches, or plastics based inor- ganic groundcovers such as polyethylene or polypropylene plastic or woven mats (Litzow and Pellett 1983; Green and Watson 1989). Likewise, limited information is available on the impacts of living groundcovers on the establishment of trees, but some reports of allelopathic influences (Walters and Gilmore 1976; Todhunter and Chan 1979) or at least competitive effects (Green and Watson 1989; Downer and Hodel 2001; Arnold and McDonald 2008) of turfgrass has been reported on tree establishment.

Taxodium distichum and C. canadensis were selected as the test species since they are commonly planted and have contrasting tolerances to urban sites. Cercis canadensis represents a species native to woodland edges and areas with well-drained soils (Arnold 2008). Cercis canadensis is popular for its ornamental foliage, growth form, and spring flowers, but tends to be susceptible to mechanical bark injury, grows poorly on compacted soils, and is often short-lived in urban landscapes in southern U.S. (Gilman 1997; Arnold 2008). Alternately, T. distichum is native to wet sites with poorly drained soils, but also tolerates drier sites, and is known to perform well in many urban sites with slightly alkaline to acidic soils with attention to appropriate provenances (Gilman 1997; Arnold 2008).

The objectives of the experiments presented herein were to: 1) compare effects of a range of commonly utilized inorganic and organic mulches, living groundcovers, and seasonal rotations of herbaceous annuals on establishment of $C$. canadensis; and 2) compare the effects of various colors of brick-on-sand pavers on the establishment of two tree species, $T$. distichum which is tolerant of urban conditions and $C$. canadensis which is less tolerant of urban conditions, high root zone temperatures, and reflected irradiances. 


\section{MATERIALS AND METHODS}

\section{Study 1: Organic Mulches, Inorganic Mulches, and Living Groundcovers Impact Eastern Redbud Establishment}

Forty planting pits of $1.1 \mathrm{~m} \times 1.5 \mathrm{~m}(3.5 \mathrm{ft} \times 5 \mathrm{ft})$ dimensions were established at the Texas A\&M University Horticulture Gardens (lat. 30E37.78'N. long. 96E20.51'W.) in College Station, Texas, U.S., on May 29, 1998. Cells were established in existing $3.7 \mathrm{~m} \mathrm{x} 12.2 \mathrm{~m}(12 \mathrm{ft} \times 40 \mathrm{ft})$ beds filled with a Silawa fine sandy loam (siliceous, thermic ultic haplustalfs, $73 \%$ sand, $9 \%$ clay, $18 \%$ silt) surrounded by treated landscape timbers. Soils in the pits were tilled to a $25.4 \mathrm{~cm}$ (10 in) depth. Cells were divided by sinking sheet metal edging $20.3 \mathrm{~cm}$ ( 8 in) deep to contain surface roots beneath the individual soil surface treatments. Irrigation was provided via stationary risers installed at $30.4 \mathrm{~cm}$ (12 in) above grade level with a $100 \%$ overlapping spray pattern. Irrigation was applied twice weekly to maintain adequate moisture by pulse irrigating for $20 \mathrm{~min}$. intervals until tensiometer readings in the soil returned to below $-15 \mathrm{kPa}$ ( -0.15 bars). Forty 23.3 L (\#7) container grown Cercis canadensis var. texensis 'Alba' grafted on C. canadensis var. texensis seedling rootstocks were obtained in advance from Turkey Creek Farms, Humble, $\mathrm{TX}$, and acclimated on site for 10 days prior to transplanting to the planting pits. Trees were established one to the center of each planting pit prior to the imposition of soil surface treatments.

Eight soil surface treatments were imposed with five replicates each. The control consisted of bare soil with no cover. The remaining seven treatments consisted of $7.6 \mathrm{~cm}$ (3 in) depth of pine bark mulch; Trachelospermum asiaticum on $30 \mathrm{~cm}$ (12 in) centers mulched with $7.6 \mathrm{~cm}$ of pine bark; solid-sodded Stenotaphrum secundatum; $7.6 \mathrm{~cm}$ of white decorative gravel (Parkers River Pebbles, Pursell Industries, Inc., Sylacauga, AL); $2.5 \mathrm{~cm}$ (1 in) of recycled paper mulch (EnviroGuard ${ }^{\mathrm{TM}}$ landscape mulch, Tascon, Inc., Houston, TX); $9.8 \mathrm{~cm}$ x $19.8 \mathrm{~cm}$ x $6 \mathrm{~cm}$ (3.89 in x 7.8 in $x 2.36$ in) brick pavers underlied with $5.1 \mathrm{~cm}$ ( 2 in) of coarse builder's sand (brick-on-sand); and seasonal color mulched with $7.6 \mathrm{~cm}$ of pine bark. The seasonal herbaceous color plant rotation for summer, fall/winter, and spring was Catharanthus roseus (L.) G. Don 'Raspberry Cooler', Viola $\times$ wittrockiana Gams. 'Crown Yellow', and Petunia $\times$ hybrida Hort. Vilm.-Andr. 'Dreams Red', respectively. Plots containing turfgrass were mown weekly at a height of $5.1 \mathrm{~cm}(2 \mathrm{in})$ throughout the growing season using handheld clippers. Plots were fertilized with a $13 \mathrm{~N}-5.7 \mathrm{P}-10.8 \mathrm{~K}$ granular fertilizer (Pursell Industries, Inc., Sylacauga, AL) at the rate of $0.45 \mathrm{~kg}(1 \mathrm{lb})$ of actual $\mathrm{N}$ per $92.9 \mathrm{~m}^{2}\left(1000 \mathrm{ft}^{2}\right)$ of bed surface in April, June, August, and October. Just prior to installation of the soil surface treatments, five randomly distributed soil core samples were extracted using a $2.5 \mathrm{~cm}$ internal diameter soil corer (Arts Manufacturing \& Supply, American Falls, ID). At harvest of the experiment, five replicate samples were taken from beneath each of the eight soil surface treatments. Cores were extracted from $1.3 \mathrm{~cm}(0.5 \mathrm{in})$ below the mulch layer to a depth of $10 \mathrm{~cm}$ ( $3.9 \mathrm{in})$ and dried at $50^{\circ} \mathrm{C}\left(122^{\circ} \mathrm{F}\right)$ to a constant mass. These cores were used to estimate soil bulk density. A duplicate set was extracted at the same time and used to measure soil $\mathrm{pH}$ (Accumet ${ }^{\circledR}$, Model 20, pH/conductivity meter, Fisher Scientific, Pittsburgh, PA).

Soil moisture potential was measured weekly from April through September using tensiometers (Model 2725 JetFill Tensiometers, Soil Moisture Equipment Corp., Santa Barbara, CA) inserted to a $15.2 \mathrm{~cm}$ ( 6 in) depth. Midday xylem water potentials to estimate maximal water stress and subsequent pre-dawn xylem water potentials to estimate recovery from water stress were determined monthly for each tree using a pressure chamber (Model 610, PMS Instrument Company, Albany, Ore). A single, recently fully expanded leaf was detached and immediately placed in the chamber for measurement in the field for each tree. Midday water potentials were determined between noon and 2:00 pm. Pre-dawn water potentials were determined between 3:30 am and dawn. Tree height, trunk diameter at $15.2 \mathrm{~cm}$ above the soil surface, and foliar stress ratings were recorded monthly during the growing season. Foliar stress ratings, as described in Arnold et al. 2005 and Arnold et al. 2007, were estimated as the proportion of the canopy to the nearest $10 \%$ exhibiting chlorosis, necrosis or abscission in the canopy. Transpiration and stomatal conductance were measured on October 21, 1999 (Portable Photosynthesis System Model Li6200 with a $\mathrm{CO}_{2}$ Analyzer Model 6250, Li-Cor, Lincoln, NE), with mean PPFD, leaf temperatures, and relative humidity of 956 mmols ${ }^{-1} \cdot \mathrm{m}^{-2}, 27.2^{\circ} \mathrm{C}\left(81.0^{\circ} \mathrm{F}\right), 20.8 \%$, respectively. Root-zone [0 to $10.2 \mathrm{~cm}$ ( 0 to $4 \mathrm{in})$ depth] and trunk temperatures $(15.2 \mathrm{~cm}$ height) were monitored on May 6-18, 1999, using $10.2 \mathrm{~cm}$ (4 in) Cole-Parmer 400 series thermistor penetration probes attached to a logging Digi-Sense ${ }^{\circledR}$ scanning thermocouple thermometer (ColeParmer, Vernon Hills, IL). Three recently fully expanded leaves were selected from the south side of each tree for transpiration and stomatal conductance measurements. Throughout the second growing season, percent of the soil covered by the soil surface covers and the percentage of the soil surface covered by weeds were estimated monthly during the growing season to assess the efficacy of the soil surface cover in suppressing weed establishment. After weed estimates were recorded, the weeds were removed by hand weeding. Tree height, caliper at $15.2 \mathrm{~cm}$ above the soil surface, and foliar stress ratings were measured monthly during the growing season. Trees were harvested in December 1999.

The statistical design was a completely random design and was analyzed using Proc GLM procedures in SAS system for Windows, Release 9.1 (SAS Institute Inc., Cary, NC). Dead trees were treated as missing data points for measurements taken on dates after death. A oneway analysis of variance was used for measures taken on a single date, while those taken on multiple dates were analyzed as a two-way analysis of variance with soil surface treatments and dates as the main effects. When they were significant $(P \leq 0.05)$, treatment by time interactions were presented. If interactions were not found to be significant, then the main effects of treatments were tested. Where significant $(P \leq 0.05)$ effects were found, means were compared using the least squares means procedures.

\section{Study 2: Masonry Color Affects on Tree Establish- ment with Brick-on-Sand Pavement}

\section{Texas Redbud Responses}

In April 2001, twenty of the planting pits were reestablished with Cercis canadensis var. texensis 'Alba' using four surface coverage treatments with five randomly distributed replications of each treatment. The control was a bare or fallow soil surface. The other treatments consisted of three colors of decorative concrete brickshaped pavers (Bermuda design pavers, Matt Stone, Inc., Tampa, FL) on a $5.1 \mathrm{~cm}$ deep bed of builder's sand with an open space in the center for the tree. Brick colors ranged from a pale blond tan, red-brown, to a dark charcoal color. Bricks were chosen with the 
aid of the manufacturers to reduce variation in physical and chemical properties, aside from color, to the greatest extent possible.

Irrigation was applied as explained in the previous study. Soil moisture potential was measured weekly from April through September using tensiometers (Model 2725 JetFill Tensiometers, Soil Moisture Equipment Corp., Santa Barbara, CA). Pre-dawn and midday xylem water potentials were determined monthly during the growing season for each tree using a pressure chamber as previously described. Tree height, trunk diameter at $15.2 \mathrm{~cm}$ above the soil surface, and foliar stress ratings were recorded monthly during the growing season. Temperatures in the top $10.2 \mathrm{~cm}$ of soil or sand, and in the atmosphere at 1.3 $\mathrm{cm}(0.5 \mathrm{in})$ above the surface of the soil or bricks, were measured as previously described during July 9-13, 2001. Reflected visible light (LI-185B and LI-210SP photometric sensor, LI-COR, Lincoln, NE) and atmospheric temperatures at 5.1, 15.2, 30.4, and $90 \mathrm{~cm}(2,6,12$, and 36 in, i.e.; from ground level to just below the canopy) were recorded for three plots from each treatment between noon and 2:00 pm on July 6, 2001. In these cases, sensors were aimed downward facing the soil surface at the appropriate heights to measure reflected and horizontally diffused light, rather than skyward when measuring ambient sunlight. The experiment was discontinued after the first year due to excessive loss of redbud trees in the brick treatments near the end of the year. Data was analyzed as described in the first experiment.

\section{Baldcypress Responses}

On November 28, 2001, the brick-on-sand experiment was reestablished utilizing Taxodium distichum as a test species, due to its ability to better withstand adverse conditions in the region (Arnold 2008). Temperatures in the top $10.2 \mathrm{~cm}$ of soil or sand, in the atmosphere at $2.54 \mathrm{~cm}(1 \mathrm{in})$ above the surface of the soil or bricks, were measured as previously explained from November 15-24, 2002. Growth, stem xylem water potentials, and soil water potentials were monitored as previously described, except that an entire stem tip was used for xylem water potential determinations with baldcypress in place of the single leaves used with the Texas red- buds. Additionally, in December 2002, bricks, sand, and soil were excavated to a depth of $20.3 \mathrm{~cm}$ (8 in) and roots sifted from the substrates outside of the originally planted root ball. These roots were dried [three days at $\left.50^{\circ} \mathrm{C}\left(122^{\circ} \mathrm{F}\right)\right]$ and a mean regenerated root density (mass per unit volume) was calculated for each planting pit. Data were analyzed as described in the first experiment.

\section{RESULTS AND DISCUSSION}

\section{Study 1: Organic Mulches, Inorganic Mulches, and Living Groundcovers Impact Eastern Redbud Establishment}

Survival was $100 \%$ during the first year, while five trees were lost during the second year, one each in the bare soil, ornamental aggregate, and T. asiaticum plots, while two from the brick-on-sand plots were lost. Also, a third tree had nearly defoliated by autumn in the brick-on-sand plots. Interestingly, all of the soil surface covers resulted in a greater height and trunk diameter growth for surviving trees of $C$. canadensis than the bare soil treatment (Table 1), except brick-on-sand which had similar height growth as the bare soil treatment. This was the case even with those treatments where living groundcovers were used that might have competed with the trees for water and nutrients. Pine bark mulch resulted in lower percentages of the canopy of $C$. canadensis exhibiting foliar stress symptoms in comparison to recycled paper or brick-onsand treatments (Table 1). While all trees survived during the first growing season after transplant; on average, $90 \%$ of the canopy of trees in brick-on-sand plots exhibited symptoms of foliar stress (e.g., chlorosis, marginal necrosis or abscission). Litzow and Pellett (1983) reported better growth of Fraxinus pennsylvanica Marsh., with several types of organic mulches compared to bare soils.

Trees grown in pine bark mulch also had less negative mean midday xylem water potentials throughout the season than those grown in bare soil, or with recycled paper, St. Augustinegrass, decorative gravel, or brick-on-sand treatments (Table 1). However, all except the trees in brick-on-sand treatments recovered from the prior day's maximal midday water

Table 1. Effects of soil surface covers on tree growth, physiological measures, and soil moisture potential. Growth of Texas redbuds were compared in simulated $1.1 \mathrm{~m} \times 1.8 \mathrm{~m}$ (3.5 ft $\times 6 \mathrm{ft})$ planting pits with surfaces covered with bare soil or one of seven combinations of organic, inorganic or living groundcovers.

\begin{tabular}{|c|c|c|c|c|c|c|c|c|c|}
\hline \multicolumn{10}{|c|}{ 1st Year } \\
\hline \multirow[b]{2}{*}{$\begin{array}{l}\text { Soil surface } \\
\text { treatment }\end{array}$} & \multirow{2}{*}{$\begin{array}{l}\text { Tree } \\
\text { height } \\
(\mathrm{cm})\end{array}$} & \multirow{2}{*}{$\begin{array}{l}\text { Trunk } \\
\text { diameter } \\
(\mathrm{mm})\end{array}$} & \multirow{2}{*}{$\begin{array}{l}\text { Foliar stress } \\
\text { symptoms } \\
\text { (\% of canopy) }\end{array}$} & \multicolumn{2}{|c|}{ Xylem water potential ${ }^{2}$} & \multicolumn{2}{|c|}{ Soil water ${ }^{2}$} & \multicolumn{2}{|c|}{ Soil } \\
\hline & & & & $\begin{array}{l}\text { Midday } \\
(\mathrm{MPa})\end{array}$ & $\begin{array}{l}\text { Predawn } \\
(\mathrm{MPa})\end{array}$ & $\begin{array}{l}\text { potential } \\
(\mathrm{kPa})\end{array}$ & $\begin{array}{l}\text { Transpiration }{ }^{y} \\
\left(\mathrm{~mol} \cdot \mathrm{m}^{-2} \cdot \mathrm{s}^{-1} \mathrm{H}_{2} \mathrm{O}\right)\end{array}$ & $\begin{array}{l}\mathrm{pH}^{\mathrm{x}} \\
\text { (pH units) }\end{array}$ & $\begin{array}{l}\text { Bulk density } \\
\left(\mathrm{g} \cdot \mathrm{cm}^{-3}\right)\end{array}$ \\
\hline Bare soil & $183 b^{\text {vu }}$ & $28.6 b^{v u}$ & $42 \mathrm{bc}^{\text {tu }}$ & $-2.35 b^{\text {tu }}$ & $-0.50 a b x^{u}$ & $-15.4 \mathrm{de}^{\mathrm{tz}}$ & $3.778 \mathrm{abc}^{\mathrm{su}}$ & $6.88 \mathrm{a}^{\mathrm{v}}$ & $1.14 \mathrm{~b}^{\mathrm{v}}$ \\
\hline Pine bark mulch & $207 \mathrm{a}$ & $34.7 \mathrm{a}$ & $30 \mathrm{c}$ & $-1.99 \mathrm{a}$ & $-0.41 \mathrm{a}$ & $-13.3 \mathrm{~cd}$ & $4.560 \mathrm{ab}$ & $6.80 \mathrm{ab}$ & $1.20 \mathrm{ab}$ \\
\hline Recycled paper & $209 \mathrm{a}$ & $33.6 \mathrm{a}$ & $76 \mathrm{ab}$ & $-2.30 \mathrm{~b}$ & $-0.43 \mathrm{a}$ & $-16.2 \mathrm{de}$ & $3.473 \mathrm{bc}$ & $6.81 \mathrm{ab}$ & $1.12 \mathrm{~b}$ \\
\hline Asian jasmine & $200 \mathrm{ab}$ & $33.8 \mathrm{a}$ & $66 a b c$ & $-2.14 a b$ & $-0.44 \mathrm{a}$ & $-9.9 b$ & $2.885 \mathrm{c}$ & $6.67 \mathrm{~b}$ & $1.10 \mathrm{~b}$ \\
\hline Rotated annuals & $215 \mathrm{a}$ & $34.5 \mathrm{a}$ & $38 \mathrm{bc}$ & $-2.21 a b$ & $-0.45 \mathrm{a}$ & $-17.9 \mathrm{e}$ & $4.718 \mathrm{ab}$ & $6.91 \mathrm{a}$ & $0.94 \mathrm{c}$ \\
\hline Decorative gravel & $208 \mathrm{a}$ & $35.3 \mathrm{a}$ & $54 \mathrm{abc}$ & $-2.27 b$ & $-0.46 \mathrm{a}$ & $-10.8 \mathrm{bc}$ & $3.702 \mathrm{abc}$ & $6.85 \mathrm{a}$ & $1.14 \mathrm{~b}$ \\
\hline Brick-on-sand & $185 \mathrm{~b}$ & $34.7 \mathrm{a}$ & $90 \mathrm{a}$ & $-2.28 b$ & $-0.60 b$ & $-6.6 a$ & $3.670 \mathrm{abc}$ & $6.89 \mathrm{a}$ & $1.28 \mathrm{a}$ \\
\hline
\end{tabular}

${ }^{2}$ Values are means of eight monthly observations from each of five plots per treatment.

y Transpiration was measured on October 21, 1999.

${ }^{\mathrm{x}}$ Initial soil $\mathrm{pH}$ on the site was $6.84 \pm 0.06$.

${ }^{\mathrm{w}}$ Initial soil density on the site was $1.17 \pm 0.05 \mathrm{~g} \cdot \mathrm{cm}^{-3}\left(0.42 \pm 0.002 \mathrm{lb} \cdot \mathrm{in}^{-3}\right)$.

${ }^{v}$ Values represent mean of 5 observations.

"Means followed by the same letters within a column are not different at $P<0.05$ level using least squares means procedure.

${ }^{t}$ Values represent mean of 40 observations.

${ }^{s}$ Values represent mean of 15 observations. 
stress to similar predawn water potentials (Table 1). While the more negative predawn xylem water potentials of $C$. canadensis in brick-on-sand treatments may have contributed to the poor survival rates and foliar stress ratings relative to the other treatments, it was not likely attributable to a lack of available soil moisture as the brick-on-sand soils had less negative soil water potentials than any of the other treatments (Table 1).

Asian jasmine plots had the next, least negative soil water potential, while rotated annuals, recycled paper, and bare soils had the most negative soil water potentials (Table 1). This might be expected for bare soils which would likely have higher rates of evapotranspiration from the uncovered soil than those with a surface cover. The plots with herbaceous annuals might also be expected to have more negative soil water potentials as the annuals would also compete for available moisture with the trees. This study observed that the recycled paper mulch tended to form a crust-like surface as it dried after wetting which may have impeded penetration of precipitation or surface applied irrigation. Although soil moisture was available for trees in the Asian jasmine plots, these trees had the lowest transpiration rates when measured near the end of the study (Table 1), suggesting some competition may have been underway between the trees and Asian jasmine for the available soil moisture.

It was interesting to note that while St. Augustinegrass may have-on average across the growing season-induced some water stress relative to pine bark treatments, by the time transpiration was sampled in autumn (Table 1), C. canadensis in St. Augustinegrass plots had one of the greater transpiration rates. This may have been due to the slower growth of St. Augustinegrass, which is a warm season turfgrass (Duble 1996; Arnold 2008), during the cooler temperatures of autumn which would have minimized its competition for soil moisture. Increased transpiration and stomatal conductance of various cultivars of crapemyrtle (Lagerstroemia indica L.) in containers on Bermudagrass turf (Cynodon dactylon L.) surfaces were reported in comparison to pine bark mulched surfaces or bare soil (Zajicek and Heilman 1991); however, this represented only effects of canopy modifications of light or heat reflectance and/or relative humidity as no root interactions were possible between the turf and trees in their study. Green and Watson (1989) report increased trunk diameter and crown growth of Acer saccharinum Marsh., grown

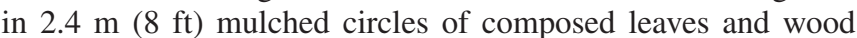
chips relative to trees with an unspecified turfgrass growing up to the trunks. They also report reduced tree root density under the turfgrass relative to mulched surfaces. Growth of $F$. pennsylvanica during establishment was reported to increase in proportion to the surface areas of Bermudagrass turf controlled either manually, chemically, or with pine bark mulch beneath the tree canopy (Arnold and McDonald 2008). These results concurred with the results of the previous two studies in respect to mulches generally promoting increased tree growth; however, the St. Augustinegrass in our study did not impede the growth of $C$. canadensis or reduce tree transpiration (Table 1). This might be due to species differences in the trees or turfgrasses, differences in irrigation practices among the studies, or perhaps due to the time of year in which transpiration measurements were collected.

Asian jasmine achieved nearly $90 \%$ soil surface coverage within three months, and St. Augustinegrass maintained a high degree of coverage ( $88 \%$ to $100 \%$ ) until late in the season, from $71 \%$ to $72 \%$, when temperatures cooled. Surface coverage by ro- tated herbaceous annuals was variable (20\% to $95 \%$ ) as seasonal color changes were removed and new ones established. Herbaceous annual color coverage was greatest in the spring transition season (95\% in April with $P . \times$ hybrida) and latter portion of the summer annual season (72\% to $74 \%$ from August to October with C. roseus). The extensive mass of herbaceous tissues on the annuals during these periods likely contributed to the drying of the soils in these treatments noted earlier (Table 1). Despite the necessity of shallow soil disturbance when removing and installing color changes, no adverse effects on tree growth or transpiration were observed (Table 1). Installation of color changes was done by digging small holes as close as possible to accommodate the herbaceous plants' root balls and these were typically small plants [six-cell packs, $158 \mathrm{~cm}^{3}\left(9.64 \mathrm{in}^{3}\right)$ in each cell]. A greater effect might have been seen on tree growth if more root zone disturbance were to have occurred if the plots with herbaceous annuals were tilled, or if herbaceous plants with larger root balls were planted.

Weed cover on control plots was greatest in April (7.8\% of surface area), May [19\%, mostly spurge (Euphorbia L.) and dallis grass (Paspalum dilatatum Poir.)], and September [33\%, mostly spurge and yellow nutsedge (Cyperus esculentus L.)]. Weed cover on control plots was greater $(P \leq 0.05)$ than that of most other surface covers throughout the season, with the exception of June and July when weed growth was less than $2.8 \%$ on all treatments. Decorative gravel had the second most extensive weed invasion in April (4\%), May (6.2\%), and September (13.2\%), but only differed statistically $(P \leq 0.05)$ from the other soil surface covers (aside from bare soil) in September. It is interesting to note that of surviving $C$. canadensis, the lowest percentage increases in trunk diameter were associated with the two soil surface treatments which permitted the most weed growth, even though weed growth was very low in most treatments throughout the growing season. Aside from those instances enumerated above weed coverage was between $0.2 \%$ and $5.6 \%$, in all treatments.

Gilman (1997) suggests that weed control was second only to irrigation as a cultural factor in initial establishment of landscape trees. Downer and Hodel (2001) reported that the primary benefit of mulching palms (Arecaceae C.F. Schultz) where water deficits occur might be the control of turfgrasses as competing weed species. Skroch et al. (1992) reported that several organic (pine bark, hardwood bark, cedar chips, and pine needles) and inorganic (polyethylene or polypropylene sheets) mulches were effective in reducing or eliminating weeds relative to bare soils, but they did not test recycled paper, gravel, rotated annuals or masonry surfaces. Weed suppression may be one reason that most any of the trees with soil surface covers, aside from brick-on-sand pavers, tended to grow better than those on bare soil. However, if this were the case one would expect to see more competition effects from the living groundcover treatments or rotations of herbaceous annuals.

Initial soil $\mathrm{pH}$ on the site prior to installation of the soil surface covers was $6.84 \pm 0.06$ and initial soil density was $1.17 \pm 0.05$ $\mathrm{g} \cdot \mathrm{cm}^{-3}\left(0.042 \pm 0.002 \mathrm{lb} \cdot \mathrm{in}^{-3}\right)$. Soil $\mathrm{pH}$ changed little among treatments during the course of the study (Table 1 ), varying only 0.25 $\mathrm{pH}$ units among all treatments, and were well within ranges suitable for most landscape plants (Foth 1990). Bulk densities did vary significantly $(P<0.05)$ by the end of the study with soils under the brick-on-sand and St. Augustinegrass turf exhibiting the greatest bulk densities compared to all other treatments except pine bark (Table 1). Some tamping of the sand beneath the bricks at installation and pressing in the St. Augustinegrass sod may explain the 
higher bulk densities of these treatments. Sequential rotation of herbaceous annuals resulted in less dense soil in comparison to all other treatments (Table 1). This is likely a result of the periodic soil disturbance and addition of organic matter associated with planting the rootballs of the herbaceous annuals three times per year. Organic soils are known to have substantially lower bulk densities than mineral or clay soils (Foth 1990; Chan 2006). However, none of the soil bulk densities in this experiment would approach levels that might be expected to impede root growth, which often occurs in the range of 1.46 to $1.75 \mathrm{~g} \cdot \mathrm{cm}^{-3}\left(0.053\right.$ to $\left.0.063 \mathrm{lb} \cdot \mathrm{in}^{-3}\right)$ depending upon the soil type (Craul 1992). Thus, changes in soil $\mathrm{pH}$ or bulk density are not likely causes for observed differences in growth responses associated with brick-on-sand treatments.

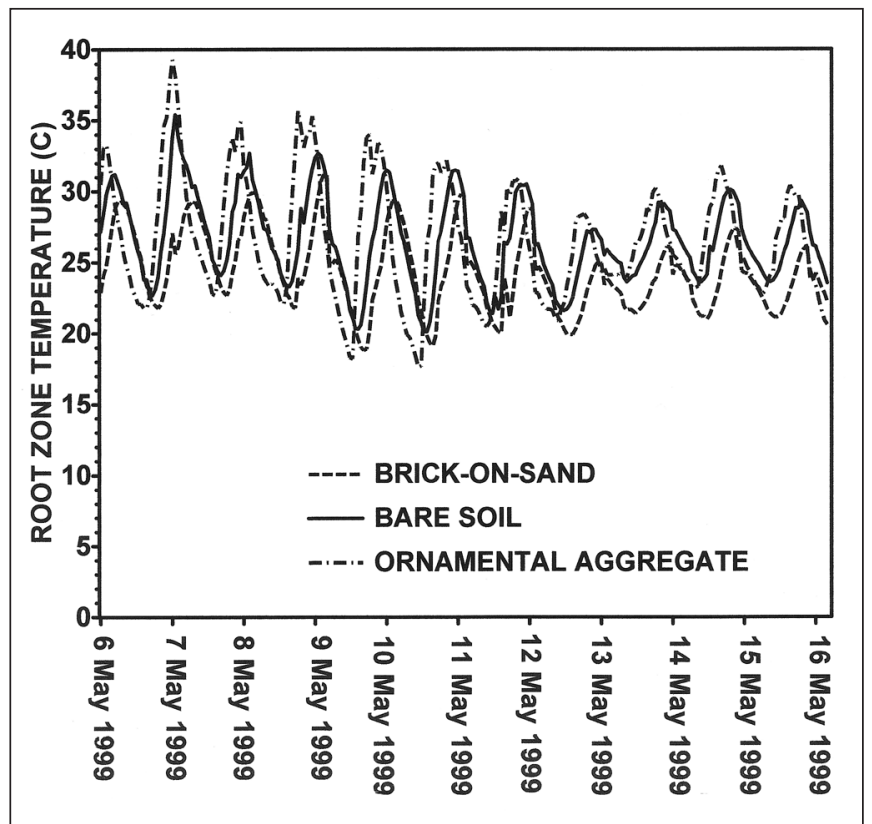

Figure 1. Late spring temperatures in the root zone for inorganic [ornamental aggregate (dotted and dashed combination line)] and brick-on-sand (dashed line) soil surface covers compared to bare soil (solid line) surrounding Cercis canadensis var. texensis. Mean high and low atmospheric temperatures for the period were $29.3^{\circ} \mathrm{C}\left(84.8^{\circ} \mathrm{F}\right)$ and $16.6^{\circ} \mathrm{C}\left(61.8^{\circ} \mathrm{F}\right)$, respectively.

Temperature monitoring of the root zone soils revealed that nonliving and living organic soil covers resulted in similar temperature patterns as those seen in bare soils (data not presented), in contrast to the inorganic covers which tended to fluctuate in both magnitude and timing from that of the bare soil (Figure 1). In the present study, the ornamental aggregate tended to heat up more quickly and to a greater extent than bare soil, which suggests that the aggregate was conducting heat rapidly into the soil. However, soils under brick-on-sand pavers when measured in spring tended to warm more slowly and to a lesser extent than bare soils, suggesting that pavers were not conducting heat as effectively into the soil (Figure 1). Kraus (1998) reported increased growth of Chilopsis linearis (Cav.) R. Sweet, with a gravel surface cover compared to bare soils. However, rather than being a general response representative of other tree species, this may be more attributable to adaptations of $C$. linearis to the high soil temperatures in its native environment, as $C$. linearis is indigenous to deserts in western North America where it is a popular heat and drought tolerant arid landscape tree (Arnold 2008). Ornamental aggregate (decorative gravel) in the present study did not increase growth of $C$. canadensis var. texensis (Table 1). In most cases, the living groundcovers also produced similar root zone soil temperatures as those in bare soil with only minor variations from that of bare soil (data not presented). Skroch et al. (1992) reported $2.2^{\circ} \mathrm{C}$ to $3.3^{\circ} \mathrm{C}$ (4EF to $6 \mathrm{EF}$ ) reductions in maximum daily soil temperatures and slightly increased minimum night temperatures under several organic mulches, but did not find temperature differences among the mulches. It should be pointed out these temperatures (Figure 1) were monitored in the spring while overall temperatures were still relatively cool at night. This may explain why the brick-on-sand treatments were somewhat cooler than bare soils as it may have required considerable heat to warm the large quantity of paving materials under these trees.

\section{Study 2: Masonry Color Affects on Tree Establish- ment with Brick-on-Sand Pavement}

\section{Texas Redbud Responses}

The particularly poor performance of $C$. canadensis in brickon-sand treatments in the first study in comparison to other soil surface treatments and the greater variations in soil temperatures associated with inorganic soil surface covers led to the question of whether or not variously colored pavers with differing reflective properties could be used to mitigate the adverse effects of brick-on-sand treatments since they were commonly used around patio and street trees. As an indirect approximation of what shortwave radition would be, photosynthetically active radiation (PAR) reflectance indicated that the lighter colored paving bricks did reflect a greater proportion of the light (full sun $\left.=2,094 \pm 8 \mu \mathrm{mol} \cdot \mathrm{s}^{-1} \cdot \mathrm{m}^{-2}\right)$ striking their upper surface at the time of measurements (Figure 2A). The bare soil had the least reflectance of light, followed closely by the dark brick-on-sand pavers. Reflected light decreased through $15 \mathrm{~cm}$ above the surface, then increased at $30 \mathrm{~cm}$ to $90 \mathrm{~cm}$ (Figure 2B). This pattern held across treatments, but was less pronounced on the bare soil and darkest brick surface. The greater PAR levels at $30 \mathrm{~cm}$ to $90 \mathrm{~cm}$ probably represent diffusion of light reflected from surrounding areas.

A differential temperature gradient existed above the treatments adjacent to the tree trunks with a $1^{\circ} \mathrm{C}\left(1.8^{\circ} \mathrm{F}\right)$ to $2^{\circ} \mathrm{C}$ $\left(3.2^{\circ} \mathrm{F}\right)$ drop in temperature from 5 to $90 \mathrm{~cm}$ above the surfaces (Figure 2B). Interestingly, atmospheric temperatures above the darker colored bricks were $1{ }^{\circ} \mathrm{C}$ to $2{ }^{\circ} \mathrm{C}$ greater than above the darker colored surface of bare soil (Figure 2B). Perhaps this is due to differential infrared reflectance or reradiated heat from the warmer soil surfaces beneath trees with darker pavers. Root zone temperatures did not appear to differ substantially among brick paver treatments, but the root zones with any of the brick surfaces were as much as $10^{\circ} \mathrm{C}\left(18^{\circ} \mathrm{F}\right)$ hotter during peak afternoon heat than those with bare soil (Figure 3). These substantially higher soil temperatures during the hottest part of summer represent a much different effect than was observed in the preceding study when temperatures were monitored during the cooler spring months (Figure 1). Time course monitoring temperature probes placed adjacent to the south side of the trunks did not reveal consistent differential patterns among the surface treatments (data not presented), suggesting that excessive trunk heating was not a cause of growth differences among treatments. 


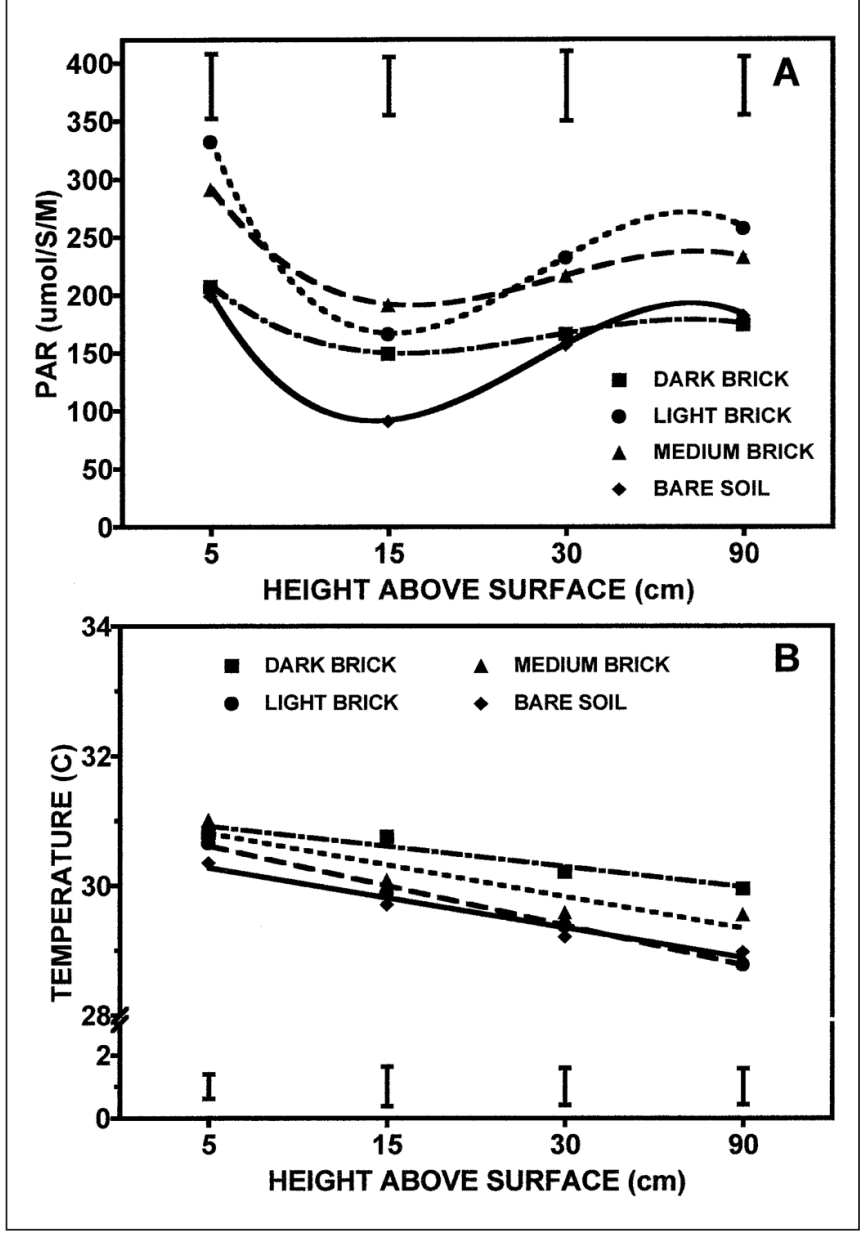

Figure 2. Photosynthetically active radiation (PAR) (A) and atmospheric temperatures (B) from near ground level into the canopy above bare soil (solid lines), or pale blond tan (light, dotted lines), red-brown (medium, dashed lines), or dark charcoal (dark, dashed and dotted combination lines) paving bricks; $n=3$; brackets indicate standard errors of the means at each height. High, mean, and low atmospheric temperatures for July 6,2001 were $35.6^{\circ} \mathrm{C}$ $\left(96^{\circ} \mathrm{F}\right), 30^{\circ} \mathrm{C}\left(86^{\circ} \mathrm{F}\right)$, and $22.8^{\circ} \mathrm{C}\left(73^{\circ} \mathrm{F}\right)$, respectively.

Kjelgren and Montague (1998) report substantially elevated leaf temperatures of F. pennsylvanica and Acer platanoides L. growing over asphalt surfaces compared to turfgrass. Mulches may buffer soil temperature fluctuations, but mulches may also increase atmospheric temperatures above them by reradiating more heat or reflected light relative to soils covered with turfgrasses and various trees and shrubs respond differently to these conditions (Montague et al. 1998; Montague and Kjelgren 2004).

Cercis canadensis grown in bare soil had greater height growth, trunk diameter increase, and a lesser proportion of the canopy exhibiting stress symptoms than the light and medium brick surface trees (Table 2). Height growth and stress symptoms were also adversely affected by dark brick surfaces (Table 2). Although the mean soil water potential for the bare soil and dark brick treatments were more negative than the light brick treatments, differences were modest, averaging from -4.9 to $-6.4 \mathrm{kPa}(-0.049$ to -0.064 bars $)$ indicating that insufficient soil moisture alone may not be responsible for the growth differences found for $C$. canadensis among treatments.

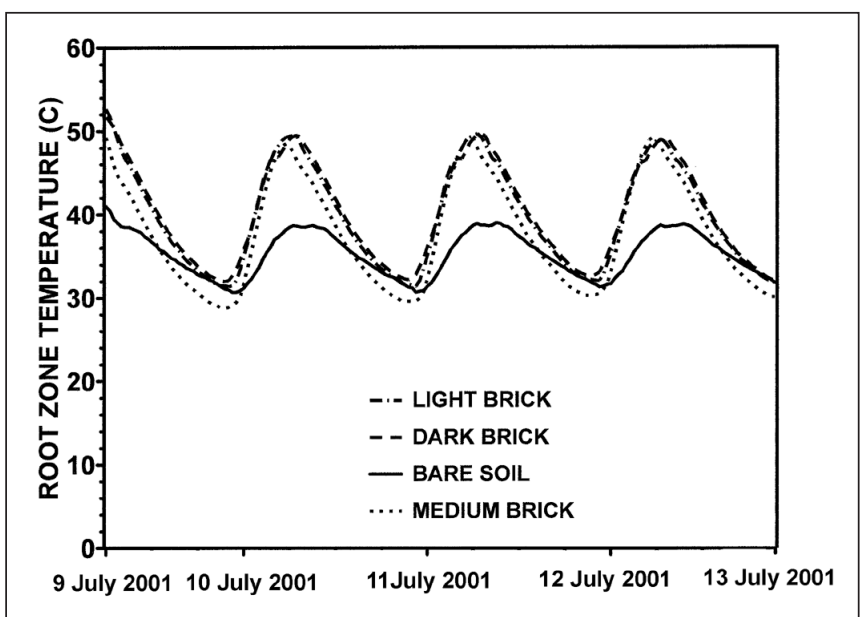

Figure 3. Summer temperatures in the root zone of Cercis canadensis var. texensis grown with soil (solid line) or pale blond tan (light, dotted and dashed combination line), red-brown (medium, dotted line), or dark charcoal (dark, dashed line) brick-on-sand paving surfaces. Mean high and low atmospheric temperatures for the period were $36.2^{\circ} \mathrm{C}\left(97.2^{\circ} \mathrm{F}\right)$ and $23.9^{\circ} \mathrm{C}\left(75^{\circ} \mathrm{F}\right)$, respectively.

Midday xylem water potentials increased during the season across treatments (data not presented), with xylem water potential differing substantially among the treatments only for C. canadensis from light colored brick treatments in August. At that time, midday xylem water potentials for trees with light bricks were more negative [-3.42 $\mathrm{MPa}(-34.2$ bars)] than trees with medium or dark bricks, or bare soil [-2.1 MPa (-21 bars), $-1.93 \mathrm{MPa}$ (-19.3 bars), or $-1.98 \mathrm{MPa}$ (-19.8 bars), respectively].

Pre-dawn xylem water potentials followed a bit different pattern. Averaged across the season (Table 2), pre-dawn xylem water potentials indicated that the best recovery (least negative water potential) from the previous day's water stress was with trees grown in bare soil, while the light colored brick trees had the poorest recovery. Pre-dawn water potentials for trees with medium and dark bricks was intermediate (Table 2). Soil water potentials were actually more negative under trees in bare soil than under those with brick-on-sand treatments, but the trees with bare soils still exhibited better pre-dawn recovery (less negative xylem water potentials) than those with brick-on-sand treatments (Table 2), suggesting that some factor other than soil moisture availability was likely involved in the responses. It is of interest to note that only trees in the bare soil treatments survived into the fall with low levels of canopy stress symptoms. All $C$. canadensis in the brick treatments were either dead or severely declining when the study was terminated in late fall. Thus, no quantitative measurements on the root systems of $C$. canadensis were made as the study was terminated. However, poor root growth out of the planted root ball was observed as the trees were removed from the plots to prepare for the next experiment (Figure 4). Results of this study suggested that any reductions in root zone heating with lighter colored brick pavers were insufficient to off-set the effects of greater light / heat reflection into the canopy by the lighter colored pavers. However, due to the early loss of the trees, these results were tentative. Thus, the entire study was repeated using a more urban tolerant tree for our region, Taxodium distichum (Arnold 2008). 
Table 2. Effects of soil surfaces on tree growth and soil water potential. Growth of Cercis canadensis var. texensis and Taxodium distichum were compared in simulated $1.1 \mathrm{~m} \times 1.8 \mathrm{~m}(3.5 \mathrm{ft} \times 6 \mathrm{ft})$ planting pits with bare soil to surfaces covered with paving bricks of three colors (pale blond tan, red-brown or dark charcoal) on a $5.1 \mathrm{~cm}(2 \mathrm{in})$ base of builder's sand.

\begin{tabular}{|c|c|c|c|c|c|c|c|c|}
\hline \multicolumn{6}{|c|}{ Cercis canadensis var. texensis } & \multicolumn{3}{|c|}{ Taxodium distichum } \\
\hline Soil treatment & $\begin{array}{l}\text { Height }^{\mathrm{z}} \\
(\mathrm{cm})\end{array}$ & $\begin{array}{l}\text { Trunk } \\
\text { Diameter }^{\mathrm{z}} \\
(\mathrm{mm})\end{array}$ & $\begin{array}{l}\text { Portion of } \\
\text { the canopy } \\
\text { with stress } \\
\text { symptoms } \\
(\%)\end{array}$ & $\begin{array}{l}\text { Soil } \\
\text { water } \\
\text { potential }^{x} \\
(\mathrm{kPa})\end{array}$ & $\begin{array}{l}\text { Predawn } \\
\text { xylem water } \\
\text { potential }^{\mathrm{y}} \\
(\mathrm{MPa})\end{array}$ & $\begin{array}{l}\text { Height }^{\mathrm{z}} \\
(\mathrm{cm})\end{array}$ & $\begin{array}{l}\text { Trunk } \\
\text { diameter } \\
(\mathrm{mm})\end{array}$ & $\begin{array}{l}\text { Root } \\
\text { density } \\
\left(\mathrm{mg} \cong \mathrm{cm}^{-3}\right)\end{array}$ \\
\hline Bare soil & $235 \mathrm{a}^{\mathrm{wv}}$ & $24.8 \mathrm{a}^{\mathrm{wv}}$ & $28 \mathrm{c}^{\mathrm{wu}}$ & $-6.4 a^{\mathrm{wt}}$ & $-0.26 c^{\text {wu }}$ & $291 \mathrm{a}^{\mathrm{wv}}$ & $70.0 \mathrm{a}^{\mathrm{wv}}$ & $1.11 \mathrm{a}^{\mathrm{wv}}$ \\
\hline Pale blond tan bricks & $215 \mathrm{bc}$ & $21.3 \mathrm{~b}$ & $44 \mathrm{ab}$ & $-5.5 b c$ & $-0.83 \mathrm{a}$ & $269 \mathrm{a}$ & $71.0 \mathrm{a}$ & $0.76 \mathrm{ab}$ \\
\hline Red-brown bricks & $200 \mathrm{c}$ & $21.6 \mathrm{~b}$ & $56 \mathrm{a}$ & $-4.9 c$ & $-0.48 \mathrm{~b}$ & $289 \mathrm{a}$ & $71.3 \mathrm{a}$ & $0.68 \mathrm{ab}$ \\
\hline
\end{tabular}

${ }^{\mathrm{z}}$ Shoot and root growth measures are values from the end of the study.

y Canopy stress symptoms and predawn xylem water potentials are means of five sample dates during growing season.

${ }^{x}$ Soil water potentials are means of 14 sample dates during growing season.

w Means followed by the same letters within a column are not different at $P<0.05$ level using least squares means procedure.

${ }^{v}$ Values represent mean of 5 observations.

"Values represent mean of 25 observations.

${ }^{t}$ Values represent mean of 70 observations.

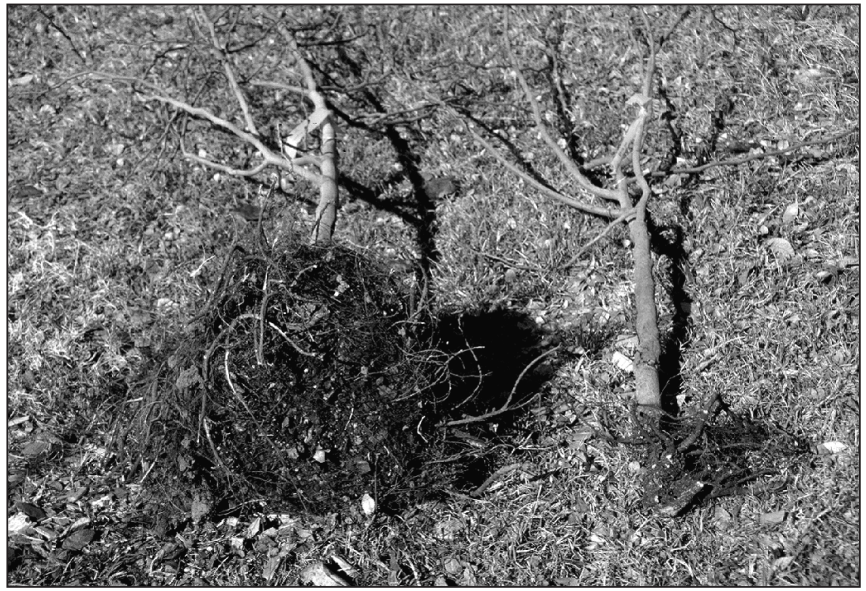

Figure 4. Examples of root balls of Cercis canadensis var. texensis removed from plots in bare soil (left) compared to root balls from brick-on-sand plots (right).

\section{Baldcypress Responses}

Surface treatments by date interactions were not significant $(P \leq 0.05)$ for tree height, trunk diameter, or root density, nor were the main effects of soil surfaces on tree height or trunk diameter growth for $T$. distichum (Table 2). No significant $(P \leq$ $0.05)$ differences among soil surface treatments, nor interactions over time, were found in predawn or mid-day water potentials for T. distichum (data not presented). However, there was a significant main effect of the soil surface treatments on root density and soil water potentials (Table 2). Soil under the lightest and darkest colored bricks had significantly $(P \leq 0.05)$ less negative water potentials than the bare soil treatment, but trees in these treatments did not grow larger. Despite drier soils in the control plots T. distichum grew similarly to those with brick-on-sand treatments. A possible explanation for this may be that trees in bare soil plots had a greater ability to access the available moisture in soil outside the original planting hole, as the control's trees had greater root density outside of the planted root ball than the darkest brick-on-sand treatment (Table 2). In general, there appeared to be a declining root density with darker brick colors (Table 2).
Alternatively, the differential water deficits between the bare soil plots and those with brick-on-sand pavers may have been too small to have induced differential growth responses, since the measured soil moisture deficits indicated reasonably moist soil conditions across treatments as would be expected given the irrigation regime. Taxodium distichum was more tolerant of the brick-on-sand treatments than was C. canadensis (Table 2) which is consistent with its purported better tolerance to urban sites (Gilman 1997; Arnold 2008). Several species native to swampy locations, like T. distichum, have been reported to have correlations among their ability to tolerate flooding and their response to supraoptimal root-zone temperatures as measured by growth, biomass accumulation, and survivorship (McLeod et al. 1986).

Temperature patterns during late autumn, after leaf drop, in the soils under $T$. distichum were very intriguing, revealing the important impacts of sun exposure to the surfaces (Figure 5). Under overcast skies on the first three days, almost no differences in soil temperatures were apparent among the various brick-on-sand treatments and bare soil (Figure 5). However during the remaining days represented in the graph (Figure 5), sunny skies and still nights prevailed resulting in as great or greater warming effects in soils of brick-on-sand treatments in comparison to bare soil as was observed for summer months in soils (Figure 3), under C. canadensis. Temperature modification objectives using various soil surface covers under trees might be quite different depending upon the climate. For instance, Litzow and Pellett (1983) report increased growth of $F$. pennsylvanica under mulches which raised soil temperatures in a cold climate (Minnesota), whereas in our work the opposite appears to be the case in a warm climate (Texas) with soil surface covers that raise the temperature.

These experiments indicate most organic and living soil surface covers were preferable to bare soils for tree establishment; however, some inorganic surface covers which are frequently utilized in suburban and urban environments could be detrimental to tree growth and survival relative to bare soil. The apparent lack of strong competition effects among living groundcovers and trees in this study may have been attributable to the well-watered and fertilized conditions, whereas living groundcovers may have exerted a greater competition effect under more resource limiting conditions. Paving surfaces, such as brick-on-sand pavers can adversely affect shoot and/or root growth, but the magnitude of such 
differences were species dependent. Soil moisture did not appear to be a limiting factor under brick-on-sand pavers, but substantial fluctuations in soil temperatures with the use of brick-on-sand pavers were observed, and the direction and magnitude of these effects were seasonally dependent. More information on the seasonal nature of temperature effects of inorganic surface covers, expanded information on species responses, and elucidation of soil surface cover effects on other parameters such as soil oxygen levels are needed to identify suitable combinations of species and soil surface covers for urban environments in different climates.

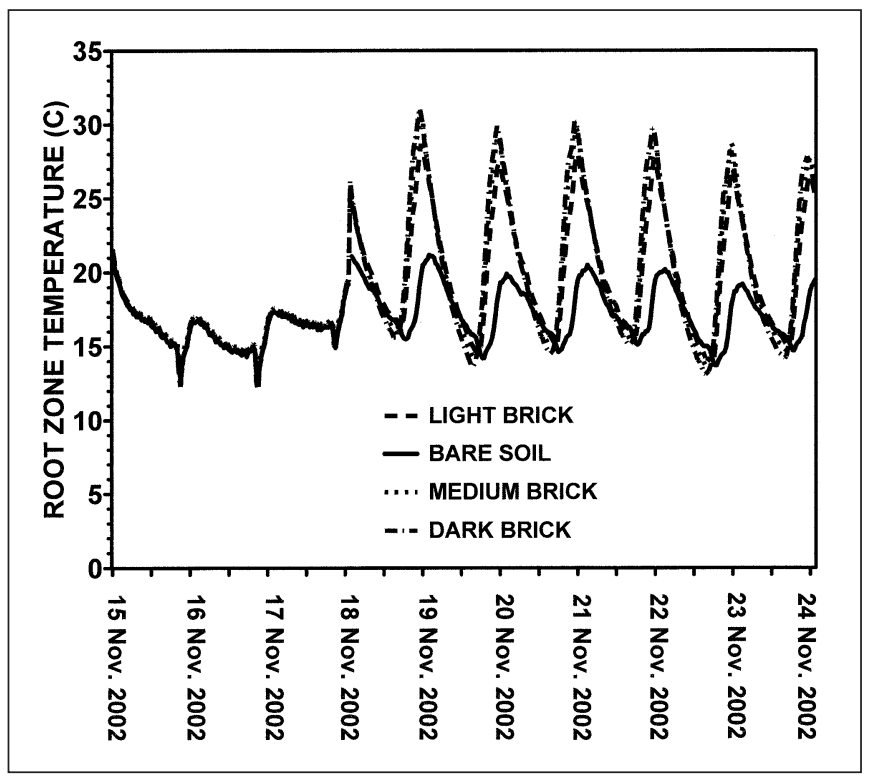

Figure 5. Autumn temperatures in the root zone under Taxodium distichum grown with soil or pale blond tan (light), red-brown (medium), or dark charcoal (dark) brick-on-sand paving surfaces. The first three days were overcast and cloudy, whereas the remaining days were dominated by cloudless skies and still nights. Trees had largely defoliated by this time allowing exposure to full sun at the soil surface. Mean high and low atmospheric temperatures for the period were $20.7^{\circ} \mathrm{C}\left(69.2^{\circ} \mathrm{F}\right)$ and $7.2^{\circ} \mathrm{C}\left(45^{\circ} \mathrm{F}\right)$, respectively.

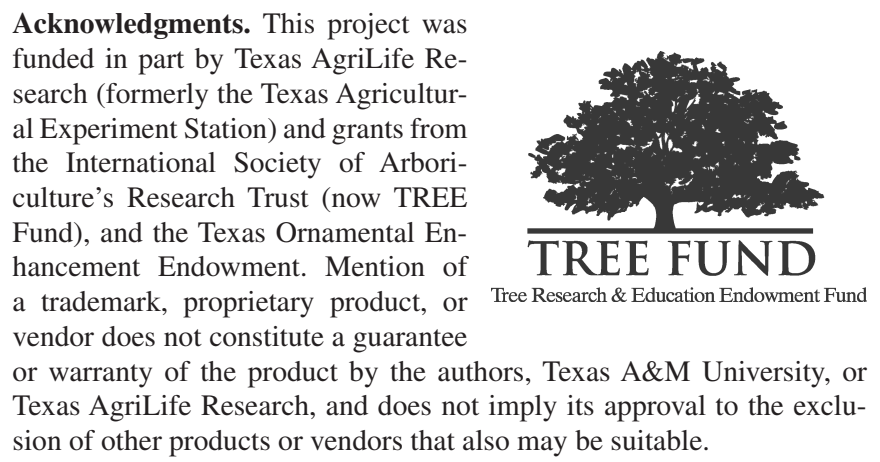

\section{LITERATURE CITED}

Arnold, M.A. 2008. Landscape Plants for Texas and Environs, Third Edition. Stipes Publishing L.L.C., Champaign, IL. p. 1334.

Arnold, M.A., and G.V. McDonald. 2008. Surface area and method of weed control surrounding green ash trunks affects landscape establishment. Proc. Southern Nursery Assoc. Res. Conf. 53:391-393.

Arnold, M.A., G.V. McDonald, and D.L. Bryan. 2005. Planting depth and mulch thickness affect establishment of green ash and bougainvillea goldenraintree. Journal of Arboriculture 31:163-170.

Arnold, M.A., G.V. McDonald, D.L. Bryan, G.C. Denny, W. T. Watson, and L. Lombardini. 2007. Below grade planting adversely affects survival and growth of tree species from five different families. Arboriculture \& Urban Forestry 33:64-69.

Ashworth, S. and H. Harrison. 1983. Evaluation of mulches for use in the home garden. HortScience 18:180-182.

Carlson, C.R. 2002. Mulch, part two: go wide, not deep. Arborist News 11(1):35-40.

Chan, K.Y. 2006. Bulk density. pp. 191-193. In: R. Lal (Ed). Encylopedia of Soil Science: Second Edition. Taylor \& Francis Group Publ., London, England.

Craul, P.J. 1992. Urban Soil in Landscape Design. John Wiley \& Sons, New York, NY. p. 396.

Downer, J., and D. Hodel. 2001. The effects of mulching on establishment of Syagrus romanzoffiana (Cham.) Becc., Washingtonia robusta H. Wendl., and Archontopheonix cunninghamiana (H. Wendl.) $\mathrm{H}$ Wendl. \& Drude in the landscape. Scientia Horticulturae 87:85-92.

Duble, R.L. 1996. Turfgrasses: Their Management and Use in the Southern Zone, Second Edition Texas A\&M Univ. Press, College Station, TX. p. 323

Duryea, M.L., R.J. English, and L.A. Hermansen. 1999. A comparison of landscape mulches: chemical, allelopathic, and decomposition properties. Journal of Arboriculture 25:88-96.

Foth, H.D. 1990. Fundamentals of Soil Science, Eight Ed. John Wiley \& Sons, New York, NY. p. 384.

Fraedrich, S.W., and D.L. Ham. 1982. Wood chip mulching around maples: effects on tree growth and soil characteristics. Journal of Arboriculture 3:85-89.

Gilman, E.F. 1997. Trees for Urban and Suburban Landscapes. Delmar Publishers. Albany, NY. p. 662.

Green, T.L., and G.W. Watson. 1989. Effects of turfgrass and mulch on establishment and growth of bare-root sugar maples. Journal of Arboriculture 15:268-272.

Hartz, T.K., and C. Giannini. 1998. Duration of composting of yard wastes affects both physical and chemical characteristics of compost and plant growth. HortScience 33:1192-1196.

Kjelgren, R., and T. Montague. 1998. Urban tree transpiration over turf and asphalt surfaces. Atmospheric Environment 32:35-41.

Kraus, H.T. 1998. Effects of mulch on soil moisture and growth of desert willow. HortTechnology 8:588-590.

Litzow, M., and H. Pellett. 1983. Influence of mulch materials on the growth of green ash. Journal of Arboriculture 9:7-11.

McLeod, K.W., L.A. Donovan, N.J. Stumpff, and K.C. Sherrod. 1986. Biomass, photosynthesis and water use efficiency of woody swamp species subjected to flooding and elevated water temperatures. Tree Physiology 2:341-346.

Montague, T., and R. Kjelgren. 2004. Energy balance of six common landscape surfaces and the influence of surface properties on gas exchange of four containerized tree species. Scientia Horticulturae 100:229-249. 
Montague, T., R. Kjelgren, and L. Rupp. 1998. Surface energy balance affects gas exchange of three shrub species. Journal of Arboriculture 24:254-262.

Skroch, W.A., M.A. Powell, T.E. Bilderback, and P.H. Henry. 1992. Mulches: durability, aesthetic value, weed control, and temperature. Journal of Environmental Horticulture 10:43-45.

Stephenson, R.E., and C.E. Schuster. 1945. Effect of mulches on soil properties. Soil Science 59:219-230.

Todhunter, M.N., and F. Chan. 1979. Effects of fescue on black walnut growth. Tree Planters Notes. Summer, 20-23.

Walters, D.T., and A.R. Gilmore. 1976. Allelopathic effects of fescue on the growth of sweetgum. Journal of Chemical Ecology 2:469-479.

Watson, G.W. 1988. Organic mulch and grass competition influence tree root development. Journal of Arboriculture 14:200-203.

Zajicek, J.M., and J.L. Heilman. 1991. Transpiration by crape myrtle cultivars surrounded by mulch, soil, and turfgrass surfaces. HortScience 26:1207-1210.

Michael A. Arnold (corresponding author)

Department of Horticultural Sciences

Texas A\&M University

Mail Stop 2133

College Station, Texas, 77843 U.S.

Garry V. McDonald

Department of Horticulture

University of Arkansas

Fayetteville, Arkansas, 72701 U.S.
Zusammenfassung. Drei Experimente untersuchten den Effekt von verschiedenen Bodendeckern bei der Pflanzung von [Cercis canadensis L. var. texensis (S. Watson) M. Hopkins 'Alba'] und [Taxodium distichum (L.) Rich.]. Das erste Experiment bestand aus acht Oberflächenbehandlungen. Die Kontrollen waren nackter Boden. Die anderen Behandlungen bestanden aus Pinienrindenmulch, [Trachelospermum asiaticum (Siebold \& Zucc.) Nakai]; St. Augustinegrass [Stenotaphrum secundatum (Walt.) Kuntze]; Zierkies, Altpapiermulch, Pflastersteine und jährliche Rotation von Stauden. Andere Experimente verglichen Pflaster in Sandbett in verschiedenen Farben von leicht blond bis holzkohlendunkel mit nacktem Boden bei der Etablierung der Bäume. Die meisten organischen und lebenden Bodendecker waren nacktem Boden vorzuziehen. Nichtorganische Bodenbedeckungen hatten einen fatalen Einfluss auf das Baumwachstum. Gepflasterte Oberflächen wiederum beeinflussten das Überleben, Trieb- und Wurzelwachstum, aber die Differenzen waren Arten-abhängig. Bodenfeuchte, $\mathrm{pH}$, und Bodendichte schienen unter dem Pflaster nicht begrenzend zu wirken, aber es konnten deutliche, saisonale Fluktuationen bei der Bodentemperatur beobachtet werden. Helle und mittlere Pflaster reflektierten mehr photosynthetisch aktive Strahlung als dunkle Pflaster oder nackter Boden. Atmosphärische Temperaturen waren über dunklen und mittleren Pflastersteinen am größten. Das Wurzelwachstum nahm mit zunehmender Verdunklung der Pflasterfarbe ab. Das Überleben und Wachstum der Cercis war mehr beeinflusst als das der Zypresse.

Resumen. Tres experimentos investigaron los efectos de varios cubre pisos en el establecimiento de Cercis canadensis L. var. texensis (S. Watson) M. Hopkins 'Alba' y Taxodium distichum (L.) Rich. El primer experimento incluyó ocho tratamientos superficiales. Los controles fueron el suelo desnudo. Los tratamientos restantes fueron mulch de corteza de pino; jazmín asiático [Trachelospermum asiaticum (Siebold \& Zucc.) Nakai]; pasto [Stenotaphrum secundatum (Walt.) Kuntze]; mulch de papel reciclado; tabiques decorativos; o rotaciones estacionales de herbáceas anuales. Otros experimentos compararon tratamientos de tabiques sobre arena, variando en color de amarillo claro a carbón oscuro, con suelo desnudo en el establecimiento de Cercis y Taxodium. La mayoría de las coberturas orgánicas y vivas fueron preferibles a los suelos desnudos; sin embargo, algunas superficies inorgánicas fueron desfavorables para el crecimiento de los árboles. Las superficies pavimentadas afectaron adversamente la supervivencia, crecimiento de raíces o brotes, pero las diferencias fueron dependientes de las especies. La humedad del suelo, $\mathrm{pH}$ y densidad aparente no parecieron estar limitadas bajo pavimentos, pero se observaron fluctuaciones estacionales en temperatura del suelo. Los tabiques amarillos reflejaron más radiación solar fotosintética que los tabiques negros o el suelo desnudo. Las temperaturas atmosféricas fueron mayores en tabiques negros. El crecimiento de las raíces disminuyó a medida que el color negro aumentó. La supervivencia y el crecimiento de Cercis fue afectado más adversamente que con Taxodium. 